\title{
Towards measuring the performance of public libraries in South Africa
}

\author{
Karin de Jager' and Mary Nassimbeni ${ }^{2}$ \\ Department of Information and Library Studies, University of Cape Town \\ kdejager@ched.uct.ac.za, mnassimbeni@ched.uct.ac.za
}

\begin{abstract}
Received: $9^{\text {th }}$ September 2003
Revised: $12^{\text {th }}$ March 2004

Following the publication of the report of the Public and Community Libraries Inventory of South Africa (Paclisa), an issue for further investigation was raised given the difficulties that many libraries had experienced in completing the questionnaire. A Working Group on Public Library Statistics (WGPLS) was established to work on the drafting of a simpler data collection instrument. Our paper describes the process of arriving at joint understanding of the aims and objectives of measuring performance in the South African public library system. A brief discussion of the purpose and rationale of collecting statistical data, and their role as performance measures and indicators for public libraries in South Africa follows. The proposed statistical form and the indicators that could be derived are presented. The paper concludes with suggestions of future steps to be taken, including a consideration by libraries of outcomes, and the difference made by libraries to people's lives.
\end{abstract}

This Project was made possible by a grant from the Carnegie Corporation of New York.

\section{Introduction}

1.1 Background to the investigation

Following the publication of the report of the Public and Community Libraries Inventory of South Africa (Paclisa), the Libraries Working Group of the Print Industries Cluster Council (PICC) raised an issue for further investigation. The Paclisa project had been set up with the following objectives:

- Collect reliable data about each public and community library

- Create a database about all the libraries

- Map the libraries' location

- Collect demographic data about the areas served by the libraries

- Obtain market information on bookspend by libraries

- Produce a directory of public and community libraries (Van Helden \& Lor, 2002)

The project, managed by the Libraries Working Group of the PICC and supported by a grant from the Carnegie Corporation of New York resulted in an inventory containing three databases:

- A library directory containing identification and descriptive data about the libraries

- A demographic database containing relevant demographic information

- A geographic database containing geographical information such as municipal boundaries and location data for the libraries (Van Helden \& Lor, 2002)

From the data collection exercise it became apparent that many libraries experienced difficulties with completing the questionnaire. Many of the questionnaires were incomplete. The only questions for which high response rates were received were questions relating to number of books in stock, number of registered users and numbers of loans (Van Helden \& Lor, 2002). This was on account of the complexity and length of the instrument, and the wide range of conditions and staff capacity in the respondent libraries.

The Carnegie Corporation of New York had agreed to make a grant to facilitate the drafting of a simple form for the regular collection of statistics from public libraries so that the database might be kept up to date. A Working Group on Public Library Statistics (WGPLS) was established by the Libraries Working Group, the team that had overseen the Paclisa project, to work on the drafting of a simpler data collection instrument. The intention of Paclisa was that the data should be collected at regular intervals so as to keep the database and directory up-to-date. The purpose of the WGPLS was to determine a set of generally agreed core public library statistics. The statistics should be of such scope that unqualified staff in small libraries would be able to collect them without requiring extensive training or intervention by the Head Office. The things or activities to be measured should be clearly and operationally defined so that uniform practice and comparability would be achieved. Guidelines and instructions for collection should accompany the core set of statistics,

I. Karin De Jager is Associate Professor, Department of Information and Library Studies, Centre for Information Literacy, University of Cape Town, South Africa.

2. Mary Nassimbeni is Associate Professor, Departrment of Information and Library Studies, Centre for Information Literacy, University of Cape Town, South Africa. 
and terminology and definitions should be standardised. The main deliverables would be a statistical form and accompanying glossary and instruction manual to guide responding libraries in the methods of data collection to be used.

\subsection{Performance measures}

At this point it could be useful to step back for a moment and to distinguish between performance measures and indicators. Measures express aspects of a library service such as size, or amount of resources, or circulation which do not by themselves express much about performance. Indicators are derived from these measures by combinations, juxtapositions or ratios that express relationships between measures. Examples of such indicators could be the average number of books borrowed by each library user or the percentage of library members in a given population.

Performance indicators may primarily be derived from four types of measures:

Input measures: such as staff, materials, funds

Process measures: everything entailed in getting the material to the service point from which they are borrowed; the things we do to make materials accessible, such as the processes of acquisition, cataloguing and shelving

Output measures: Products, services, activities, circulation, reference queries, interlibrary loans

Outcomes: take-up of services, user satisfaction

The brief of the Working Group was that public libraries in South Africa should all collect the same kinds of measures according to the same standards, eventually to enable libraries to derive indicators from these measures. The measures that were proposed for collection at this stage were input and output measures only; process measures, such as how long it takes to get a document delivered through ILL, or how quickly a returned item is reshelved, are generally regarded as for private and internal consumption, while outcome measures are more qualitative in nature and require techniques such as surveys, which may be done at individual libraries, as required.

Essential requirements for collecting standardized and comparable measures, are for standard definitions to be used in order to ensure uniform practice. Performance measures and indicators therefore have to be appropriate, reliable (unambiguous), reproducible, helpful and practical (Poll \& Te Boekhorst 1996: 18-19). A glossary was also prepared to give definitions of measures and participants' opinions, comments and input were invited on the first draft. In its final form, the glossary additionally gave instructions for completing the form.

It is generally recognized that performance indicators enable libraries to address some or all of the following issues:

- to manage effectively and to enable benchmarking

- to improve their performance

- to set priorities

- to identify problem areas

- to allow for comparability both across time and between institutions

- to give a rounded picture of all aspects of library use

- to enable local, state and national advocacy for investment in libraries to enable them to make an even better contribution to society and the economy

To summarise therefore: "Statistical information is necessary to formulate sound policy advice, to analyse and predict trends, to monitor performance, to market effectively and to seek funding successfully" (Bundy, 2000). As competition for funds among service organisations has grown ever stronger in recent years, the need for statistical evidence of providing needed services, is "probably the most important reason for the increasing interest in effectiveness and performance measures" (Willemse, 1989).

\section{Methodology}

2.1 Building consensus

At the end of $200 \mathrm{I}$ an invitation was sent out to heads of respondent libraries to join the WGPLs or to send a nominee. Those who accepted the invitation, constituted, with the convenors, the Working Group on Pubic Library Statistics. Representatives from twelve provincial and metropolitan libraries joined the group. The WGPLS started work on 29 April 2002 with the launch of an e-mail discussion group, the initial vehicle for consultation and discussion among the members. It was agreed that a sensible starting point would be to analyze current practice and to see to what extent common ground was covered by all the libraries. Accordingly members submitted the statistical forms currently in use, and the convenors analyzed them with a view to isolating common elements to be incorporated in the first draft. The first draft of the statistical form was presented by the convenors at the first meeting of the WGPLS held during the Liasa Conference in Port Elizabeth on 3 October 2002. The draft form was compiled using the following methods:

- Examination of the statistical forms sent by members of the WGPLS

- Inputs and suggestions made by the members on the WGPLS e-mail discussion forum

SA Jnl Libs \& Info Sci 2005, 7I(I) 
- Examination of the Paclisa questionnaire

- Study of the international literature

- Examination of various international standards

- Examination of the National Center for Education Statistics annual report, Public libraries in the United States: fiscal year 1999

Using these sources, the convenors compiled a list of measurement categories, paying particular attention to the commonly used categories by participating libraries. This first draft statistical form was accompanied by a glossary. The workshop was useful in that participants discussed the purpose and rationale of collection of statistics, and their role in performance measures and indicators for public libraries in South Africa. Participants agreed on the following points of departure:

- An important design principle would be the reasons why the data would be collected and the purpose to which the information would be put

- It was recognized that there are different levels of operation (local and provincial)

- There was an interest that we should aim eventually at international comparison

- The best way of approaching the task would be to aim at identifying a core set of measures that everybody could agree on

The convenors undertook to generate a list of measures and indicators which would form the basis for discussion at the follow-up workshop to be held towards the end of the year in Cape Town. The purpose of this workshop would be to consider a revised statistical form and glossary with a view to finalizing its content so that it could be distributed nationally. It was also agreed that clarity should be sought on the agency that would take responsibility for distribution of the forms and the collection exercise.

The second workshop was held in Cape Town in November 2002. It was agreed during discussions that a national information system for public libraries is necessary for policy making and for advocacy purposes. An essential requirement of the system, whatever its scope and degree of comprehensiveness, is that the data have to be reliable and comparable. The National Library of South Africa, and the Centre for Geoinformation Science at the University of Pretoria (the agency responsible for the design of the instrument and data collection in the Paclisa project) would assume responsibility for the data collection in 2003.

Some of the pitfalls of the use of data were aired. The view was expressed that some librarians are reluctant to collect statistics for fear that they might be used to the disadvantage of their library. This could lead to inflation of the figures returned. The concern about comparisons has been raised in the international literature, and is an issue that is related to the notion of national and international standards, a theme that surfaced in the workshop discussions.

For example, Thomas Hennen's annual publication of the "Great American Public Libraries: HAPLR Ratings" raises a great deal of interest among libraries and also in the media. Using data collected annually by the Federal-State Cooperative Service he ranks public libraries according to their score in a number of categories. His review is published in American libraries and always accompanied by vigorous debate, and variously defensive and triumphant responses. He notes in his latest review that German public libraries have produced a similar index, BIX, designed to produce comparisons of one library to another over time (Hennen, 2002: 68).

The United Kingdom introduced public library standards in January 200I, and libraries have three years in which to comply. It is intended that performance will be measured through a public audit process (Appendix 2: national standards). The standards cover:

- Rules (e.g. book loan period)

- Access (e.g. opening hours, geographic location)

- Materials (e.g. minimum number of stock items added)

- Quality of service (e.g. percentage of users who rate staff helpfulness positively)

- Other aspects of service provision (e.g. number of qualified staff)

- Outputs and outcomes (e.g. number of visits to libraries per 1000 capita)

Participants at the workshop expressed the view that an unintended consequence of the potential for comparison among systems might be that a library whose spending is lower than another might be held up as efficient, rather than underresourced. Concerns were expressed about the bluntness of an instrument to sketch the use and value of a service. For example, many libraries have users and readers in greater numbers than registered borrowers. This raised the difficulty of counting, and the tension between efficiency and economy. It is far easier to count registered users than to count people using the library at any given time. Further evidence for this concern was reflected in a recent report of a meeting of the tenth annual general meeting of the friends of the Observatory Public Library in Cape Town. The chair of the Friends, Dr Helen Moffatt, voiced her opposition to the use of "the number of books issued (and cost per issue) as a means of calculating the cost effectiveness of libraries". She argued that this practice favours libraries that serve more affluent, 
literate and leisured communities, and observed that more than half of the regular visitors to the Observatory Library seldom take out a book (Passionate FOOLS keep the library doors open, 2003: 6).

\subsection{Measuring performance of public libraries in South Africa}

The original brief had been to draw up a form that was as straightforward to complete and as simple as possible. At the meeting in Port Elizabeth, participants were reminded that they would be collecting measures only and that the compilation of indicators was beyond the brief of the Working Group. A need was nevertheless expressed for a small number of indicators that would be more informative than simple measures, and it was agreed that a short list of possible indicators for optional use would additionally be drawn up for discussion at the next meeting, which was held in Cape Town in November 2002.

Participants were also reminded that is not possible to draw significant conclusions from measures and indicators collected over a short period, but over a number of years they could become important in showing the relative costs and the cost effectiveness of specific library services. It was therefore important to start collecting data immediately, and to continue doing so regularly.

The issue of whether or not to include measures reflecting costs elicited considerable discussion. The IFLA guidelines suggest that they should perhaps be left out. Some librarians may be afraid of including cost measures, as they may be used inappropriately, for example to demand the most service at the least cost (Te Boekhorst, 1995: 278). In addition, a particularly low-cost service may not be a very effective one or one that meets with the needs of the users (Poll \& Te Boekhorst, 1996: 39). As was shown above, these concerns were indeed voiced by the participants. On the other hand, the print industry in South Africa was eager to have access to public library spending data, as were interest groups lobbying for issues such as the abolishing of VAT on books, or increasing spending on public libraries. Participants at both Workshops were therefore requested to consider whether or not to include cost data in the form.

\section{The statistical form}

The agreed statistical form was redrafted to take into account the participants' suggestions made in November. The final form was submitted for implementation to the National Library of South Africa in February 2003. The form is attached as Appendix A and the accompanying instructions for completion as Appendix B. As far as the question of including cost data was concerned, the participants agreed that it would be important to include a section on operating costs and one on expenditure (see sections 7 and 8 on the Form and the Completion Instructions).

\subsection{Additional performance indicators that may be compiled from the proposed core measures}

In response to specific requests from participants at the Port Elizabeth meeting, a document for the calculation of a number of fairly simple indicators, with brief descriptions of procedure was compiled and discussed. It was recognized that individual libraries might wish to calculate such indicators for their own purposes. These indicators, based on ISOI I620: 1998(E), were:

\section{General library services}

Percentage of population reached

Lending documents (collection turnover)

Loans per capita

Loans per employee

Library facilities

Use of facilities

Cost per loan

Cost per user

Library budget as a percentage of the Municipality budget

Expenditure per library member

Additional (non-ISO Standards) indicators:

Materials provision

Library materials per member

Provision of library materials from sources outside the library (ILL)

Service delivery

ILLs issued per FTE staff

Reference queries per FTE staff 
3.2 Indicators that cannot be derived from the suggested core measures

Some of the generally recognized library performance indicators such as In-house use; User satisfaction; Availability; and Seat occupancy rate, require special investigations involving sampling, which cannot be calculated from the suggested core measures. Individual libraries may choose to conduct such investigations and it is suggested that methodologies as set out in ISOI I 620 be used to ensure a standard approach.

Members of the Workshop at the LIASA conference in Port Elizabeth had expressed particular interest in gathering data about in-house use which, it has been suggested, may well exceed circulation by as much as $50 \%$ (Western Cape, $200 \mathrm{I}: 13)$. For this reason, two further indicators, also involving sampling, were suggested and explained, based on ISOI1620:

- In-library use per capita, involving a fixed sampling period during which users are asked not to reshelve documents used in the library. The used documents are counted and in-house use is calculated according to the suggested formula.

- Document use rate, which involves estimating the proportion of documents in use at any one time and expressing the documents that are in use as a percentage of documents owned by the library.

It was also pointed out that indicators are not always appropriate for reporting activities. For example the extent of Use of Extension Services (such as Exhibitions, Adult basic education classes, Lectures and talks, Story hours, Children's programmes, Reading circles and Video/film shows) are best reported in terms of the basic measures that simply state how many activities of each kind where held, and how many people attended:

A total of ...... people attended ..... activities of a particular kind.

\section{Conclusion}

So where do we go from here? The National Library of South Africa has started to distribute the questionnaires to public libraries throughout the country. But it must be clear that this is only the beginning. These are only the most basic measures, upon which one might begin to build a culture of assessment. It is most important to realize that input and output measures such as these give only the bare outline of what is happening at particular institutions and clearly they are not enough, or even most appropriate in all circumstances. They cannot give all the details and they certainly do not give any reasons why things are the way they are. For such explanations, a much rounder, fuller picture is required: for example, our membership is low, but our in-house use is very high, for the following reasons and with the following figures to back this up. Individual initiatives will have to be designed to address individual situations and needs. We need to start thinking about outcomes, about the difference we make to people's lives, and how to demonstrate this objectively. But it is also essential, and that is why these early steps are so important, to start somewhere, to see where we are according to the baseline measures, and to begin to fill in the rich picture from there.

\section{References and additional readings}

ANSI/NISO Z39.7-1995. Library Statistics. 1995.

Abbott, C. 1994. Performance measurement in library and information service. London: Aslib

Appendix 2: national standards. Electronic. Available: $h t t p: / / w w w . a u d i t-c o m m i s s i o n . g o v . u k / r e o r t s / A C-R E P O R T$.asp Bundy, Alan. 2000. Best value: libraries. Electronic. Available: http://www.alia.org.au/conferences/alia2000/proceedings/
alan.bundy.html

Carbone, P. 1995. The Committee Draft of International Standard ISO CD II620 on library performance indicators. IFLA journal, vol. 21, no. 4, p. 274-277.

Hennen, T J. 2002. Great American Public Libraries: the 2002 HAPLR rankings. American libraries, October 2002, p. 64 - 68. Electronic. Available: http://archive.ala.org/alonline/archive/hennen2002.pdf

ISO 2789: 1991. Information and Documentation: International library statistics.

ISO II 620: 1998. Information and Documentation: Library Performance Indicators.

King Research. Keys to success: performance indicators for public libraries: a manual of performance measures and indicators. London: HMSO, 1990.

LIST: library \& information statistics tables for the United Kingdom. Compiled and published for the British Library Research and Innovation Centre. Loughborough: LISU, [200I]

National Center for Education Statistics. 2002. Public libraries in the United States: Fiscal Year 1999. Washington, DC: Department of Education. Office of Educational Research and Improvement. Electronic. Available: $h t t p: / / n c e s . e d . g o v / s u r v e y s /$

Passionate FOOLS keep the library doors open. 2003. Southern suburbs tatler, Thursday 28 August 2003.

Poll, Roswitha and Te Boekhorst, Peter. 1996. Measuring quality: international guidelines for performance measurement in academic libraries. IFLA Publications 76. München: Saur.

Rural information provision in developing countries: measuring performance and impact. 1998. Paris: Unesco

Sumsion, J. 1993. Practical performance indicators - 1992: documenting the Citizens' Charter consultation for the UK Public Libraries with examples of Pls and surveys in use. Loughborough: LISU.

Te Boekhorst, Peter. 1995. Measuring quality: the IFLA guidelines for performance measurement in academic libraries. IFLA Journal, 2 I (4) 278-28I.

Van Helden, P \& Lor, P J. 2002. Paclisa final report. Pretoria: National Library of South Africa.

Van House, $\mathrm{N}$ et al. 1987. Output measures for public libraries, $2^{\text {nd }}$ ed. Chicago: ALA

Willemse, John. 1989. Library effectiveness - the need for measurement. South African journal of library and information science. 57(3);26I-266. 
Appendix A. Annual Public Library Statistical Report: Core Measures

For Financial Year :

IMPORTANT: Please consult the accompanying document "Completion Instructions" before filling in this form

I Name of library:

Library code:

Town:

Municipality:

Street Address:

Telephone number:

Postal Code:

Fax Number:

E-mail address:

2 Number of members

Adults Children Total

3 Total number of users. (Please see "Completion Instructions" for details on how to calculate this measure.)

4 Stock

4.I Number of documents in stock

\begin{tabular}{|c|c|c|c|c|c|c|c|c|c|c|c|c|c|}
\hline & Afrikaans & English & IsiXhosa & IsiZulu & Sepedi & Sesotho & Setswana & SiSwati & Tshivenda & IsiNdebele & Xitsonga & Other & TOTAL \\
\hline \multicolumn{14}{|l|}{ Adult fiction } \\
\hline \multicolumn{14}{|l|}{$\begin{array}{l}\text { Adult non- } \\
\text { fiction }\end{array}$} \\
\hline \multicolumn{14}{|l|}{$\begin{array}{l}\text { Junior } \\
\text { fiction }\end{array}$} \\
\hline \multicolumn{14}{|l|}{$\begin{array}{l}\text { Junior non- } \\
\text { fiction }\end{array}$} \\
\hline \multicolumn{14}{|l|}{$\begin{array}{l}\text { Neo- } \\
\text { literate } \\
\text { material }\end{array}$} \\
\hline \multicolumn{14}{|l|}{$\begin{array}{l}\text { Large print } \\
\text { books }\end{array}$} \\
\hline \multicolumn{14}{|l|}{ Periodicals } \\
\hline TOTAL & & & & & & & & & & & & & \\
\hline
\end{tabular}

4.2 Number of other materials in stock

\begin{tabular}{|l|l|}
\hline Compact Discs & \\
\hline Audio (music cassettes) & \\
\hline Audio books & \\
\hline Charts, maps, posters & \\
\hline Videos & \\
\hline Art prints & \\
\hline Computer programmes & \\
\hline Toys/games & \\
\hline
\end{tabular}

4.3 Number of documents acquired in the current financial year

\begin{tabular}{|l|l|l|l|l|l|l|l|l|l|l|l|l|l|}
\hline & Afrikaans & English & IsiXhosa & IsiZulu & Sepedi & Sesotho & Setswana & SiSwati & Tshivenda & IsiNdebele & Xitsonga & Other & TOTAL \\
\hline $\begin{array}{l}\text { Adult } \\
\text { fiction }\end{array}$ & & & & & & & & & & & & \\
\hline $\begin{array}{l}\text { Adult } \\
\text { non- } \\
\text { fiction }\end{array}$ & & & & & & & & & & & & \\
\hline
\end{tabular}




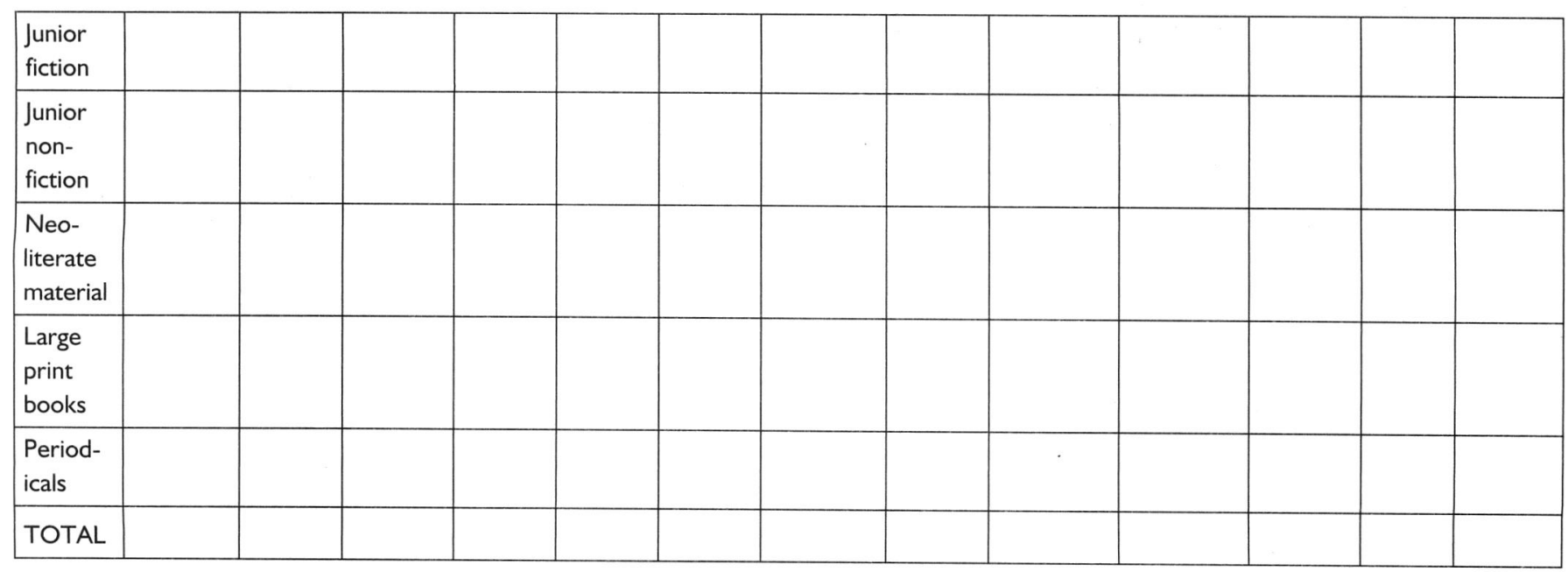

\subsection{Number of current periodical titles}

4.5 Number of other materials acquired in the current financial year

\begin{tabular}{|l|l|}
\hline Compact Discs & \\
\hline Audio (music cassettes) & \\
\hline Audio books & \\
\hline Charts, maps, posters & \\
\hline Videos & \\
\hline Art prints & \\
\hline Computer programmes & \\
\hline Toys/games & \\
\hline
\end{tabular}

\section{Circulation}

5.I Circulation of documents (Loans) per annum

\begin{tabular}{|c|c|c|c|c|c|c|c|c|c|c|c|c|c|}
\hline & Afrikaans & English & IsiXhosa & IsiZulu & Sepedi & Sesotho & Setswana & SiSwati & Tshivenda & IsiNdebele & Xitsonga & Other & TOTAL \\
\hline $\begin{array}{l}\text { Adult } \\
\text { fiction }\end{array}$ & & & & & & & & & & & & & \\
\hline $\begin{array}{l}\text { Adult } \\
\text { non- } \\
\text { fiction }\end{array}$ & & & & & & & & & & & & & \\
\hline $\begin{array}{l}\text { Junior } \\
\text { fiction }\end{array}$ & & & & & & & & & & & & & \\
\hline $\begin{array}{l}\text { Junior } \\
\text { non- } \\
\text { fiction }\end{array}$ & & & & & & & & & & & & & \\
\hline $\begin{array}{l}\text { Neo- } \\
\text { literate } \\
\text { material }\end{array}$ & & & & & & & & & & & & & \\
\hline $\begin{array}{l}\text { Large } \\
\text { print } \\
\text { books }\end{array}$ & & & & & & & & & & & & & \\
\hline $\begin{array}{l}\text { Period- } \\
\text { icals }\end{array}$ & & & & & & & & & & & & & \\
\hline TOTAL & & & & & & & & & & & & & \\
\hline
\end{tabular}


5.2 Circulation of other materials per annum

\begin{tabular}{|l|l|}
\hline Compact Discs & \\
\hline Audio (music cassettes) & \\
\hline Audio books & \\
\hline Charts, maps, posters & \\
\hline Videos & \\
\hline Art prints & \\
\hline Computer programmes & \\
\hline Toys/games & \\
\hline
\end{tabular}

\subsection{OPTIONAL. In-house use}

\section{Number of interlibrary loans per annum}

\begin{tabular}{|l|l|l|}
\hline Documents requested by other libraries & & Documents requested by other libraries within the system \\
\hline Documents received from other libraries & & Documents received from other libraries within the system \\
\hline
\end{tabular}

7 Operating Cost (Source of funds expended during the previous completed financial year)

\begin{tabular}{|c|c|c|c|c|}
\hline & $\begin{array}{l}\text { Provincial } \\
\text { Government }\end{array}$ & Municipal Government & Other & TOTAL \\
\hline Information Resources (documents and other materials) & R & R & R & R \\
\hline Staff salaries & $R$ & $R$ & $\mathrm{R}$ & $R$ \\
\hline Operational & $R$ & R & R & $R$ \\
\hline Capital Budget & $R$ & $R$ & R & R \\
\hline $\begin{array}{l}\text { TOTAL (if detail is not available, please supply total amount } \\
\text { for LIBRARY only) }\end{array}$ & $R$ & $R$ & $\mathrm{R}$ & R \\
\hline
\end{tabular}

8 Expenditure. (For Provincial Library Authorities and Metro Libraries only)

8.I Expenditure on documents in current financial year

\begin{tabular}{|c|c|c|c|c|c|c|c|c|c|c|c|c|c|}
\hline & Afrikaans & English & IsiXhosa & IsiZulu & Sepedi & Sesotho & Setswana & SiSwati & Tshivenda & IsiNdebele & Xitsonga & Other & TOTAL \\
\hline $\begin{array}{l}\text { Adult } \\
\text { fiction }\end{array}$ & $R$ & $R$ & $R$ & $R$ & $R$ & $R$ & $R$ & $R$ & $R$ & $R$ & $R$ & $R$ & $R$ \\
\hline $\begin{array}{l}\text { Adult } \\
\text { non- } \\
\text { fiction }\end{array}$ & $R$ & $R$ & $R$ & $R$ & $R$ & $R$ & $R$ & $R$ & $R$ & $R$ & $R$ & $R$ & $R$ \\
\hline $\begin{array}{l}\text { Junior } \\
\text { fiction }\end{array}$ & $R$ & $R$ & $\mathrm{R}$ & $\mathrm{R}$ & $R$ & $R$ & $R$ & $R$ & $R$ & $R$ & $\mathrm{R}$ & $R$ & $R$ \\
\hline $\begin{array}{l}\text { Junior } \\
\text { non- } \\
\text { fiction }\end{array}$ & $\mathrm{R}$ & $R$ & $\mathrm{R}$ & $\mathrm{R}$ & $R$ & $R$ & $R$ & $R$ & $R$ & $R$ & $R$ & $\mathrm{R}$ & $\mathrm{R}$ \\
\hline $\begin{array}{l}\text { Neo- } \\
\text { literate } \\
\text { material }\end{array}$ & $R$ & $R$ & $\mathrm{R}$ & $\mathrm{R}$ & $R$ & $\mathrm{R}$ & $\mathrm{R}$ & $R$ & $R$ & $R$ & $\mathrm{R}$ & $\mathrm{R}$ & $R$ \\
\hline $\begin{array}{l}\text { Large } \\
\text { print } \\
\text { books }\end{array}$ & $R$ & $R$ & $\mathrm{R}$ & $R$ & $R$ & $R$ & $R$ & $\mathrm{R}$ & $R$ & $R$ & $R$ & $R$ & $R$ \\
\hline $\begin{array}{l}\text { Period- } \\
\text { icals }\end{array}$ & $R$ & $R$ & $R$ & $R$ & $R$ & $R$ & $R$ & $\mathrm{R}$ & $\mathrm{R}$ & $\mathrm{R}$ & $\mathrm{R}$ & $R$ & $R$ \\
\hline TOTAL & $R$ & $R$ & $\mathrm{R}$ & $R$ & $R$ & $R$ & $R$ & $R$ & $R$ & $\mathrm{R}$ & $R$ & $R$ & $R$ \\
\hline
\end{tabular}

8.2 TOTAL expenditure on other library materials in current financial year 


\section{Facilities available}

\begin{tabular}{|c|c|}
\hline & Numbers \\
\hline \multicolumn{2}{|c|}{ Photocopier machines } \\
\hline \multicolumn{2}{|c|}{ Publicly available computer workstations without Internet connections } \\
\hline \multicolumn{2}{|l|}{ Seats } \\
\hline \multicolumn{2}{|c|}{ Publicly available computers with Internet connections } \\
\hline \multicolumn{2}{|c|}{ Total number of computers with Internet connections } \\
\hline Bookmobiles & 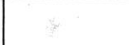 \\
\hline
\end{tabular}

10 Use of facilities: number of users per annum.

Computers Internet Seats

I I Staff (number of staff according to the following categories):

\begin{tabular}{|l|l|l|l|}
\hline & FILLED & VACANT & TOTAL \\
\hline Library Staff (FTE) & & & \\
\hline Qualified with degree & & & \\
\hline Qualified with diploma & & & \\
\hline Qualified with matric & & & \\
\hline No qualifications & & & \\
\hline Administrative (FTE) & & & \\
\hline Part-time/hourly paid & & & \\
\hline Total & & & \\
\hline Volunteers (FTE) & & & \\
\hline
\end{tabular}

\section{User Assistance: incidents per annum}

Reference and information queries

\section{I3 Formal library orientation in groups: incidents per annum}

Number of groups

Total of individuals in the groups

I4 Library floor area in square metres (including rented space)

\section{Hours of opening (per week)}

Total number of hours a library is open to the public from Monday to Sunday

\section{Extension services per annum}

\section{6.| Adult basic education classes}

\begin{tabular}{|l|l|}
\hline Number of activities & \\
\hline Total attendance & \\
\hline
\end{tabular}

Themes (please specify): 
16.2 Lectures and talks

\begin{tabular}{|l|l|l|}
\hline Number of talks/presentations & \multicolumn{2}{|l|}{} \\
\hline Total attendance & Children & Adults \\
\cline { 2 - 3 } & & \\
\hline
\end{tabular}

Themes (please specify):

16.3 Children's programmes. Please specify:

\begin{tabular}{|l|l|l|l|l|l|}
\hline & Story hours & & & & \\
\hline Number of programmes & & & & & \\
\hline Total attended & & & & & \\
\hline
\end{tabular}

16.4 Reading circles/Book reviews/Book readings

\begin{tabular}{|l|l|}
\hline Number of events & \\
\hline Total attended & \\
\hline
\end{tabular}

16.5 Video/film shows

\begin{tabular}{|l|l|}
\hline Number of shows & \\
\hline Total attended & \\
\hline
\end{tabular}

16.6 Other activities

\begin{tabular}{|l|l|l|l|l|}
\hline Please specify: & & & & \\
\hline Number of activities & & & & \\
\hline Attendance figures & & & & \\
\hline
\end{tabular}

\section{Community involvement}

Do you have any of the following community structures in your library?

\begin{tabular}{|l|l|l|}
\hline User Committee & Yes & No \\
\hline Friends of the Library & Yes & No \\
\hline Library Advisory Committee/Council & Yes & No \\
\hline Student User Committee & Yes & No \\
\hline Other (please specify) & Yes & No \\
\hline
\end{tabular}

THANK YOU VERY MUCH FOR YOUR ASSISTANCE

\section{Appendix B: Annual Public Library Statistical Report: Core Measures For Financial Year :}

Completion instructions

\section{Please study carefully before filling in the Statistical Report}

The numbers refer to the numbers of the sections in the Statistical Report. Each section gives specific instructions on how to complete that section of the Report.

PLEASE NOTE that one form should be completed for each individual library in a system. A separate form should additionally be completed by the Head Office of the system if any library activities (e.g. acquisition, cataloguing, or reference services) take place there.

I Name of library: Give here the name whereby the Library is commonly known.

Library code: Give here the SAIS (SA Interlending Scheme) number if applicable.

Street Address: Full address details are particularly important if the Library has recently changed address. 
2 Members are persons or organizations that are registered with the library in order to use its documents within or away from the library. Give the total only if adults and children are not registered separately.

3 Users. A user is a person who has visited the library or used the services of the library during the past year. The number of users with registered loans should be used as an estimate of the number of users in the target population. (from ISO B.2.I.I.3)

Please note that this measure 'users' (number of people using the library) is different from 'uses' (the number of times the library is used). See also section $\mathbf{5 . 3 .}$

\section{Stock}

4.I A document is a piece of recorded information which can be treated as a unit in a documentation process regardless of its physical form and characteristics (from ISO 2789). Treat all separate pieces of print information on paper as documents.

"Other" refers to all non-South African foreign languages.

Give total numbers of documents only if breakdowns into different languages are not available.

4.2 Number of other materials in stock: Give totals of all types of materials available in the Library.

4.3 Number of documents acquired in the current financial year: Reference materials are to be included in the non-fiction blocks

Give total numbers of documents acquired only, if breakdowns into different languages are not available.

4.4 Give the total number of periodical titles currently received by the Library. Include newspapers in the count.

4.5 Give totals of all types of other materials acquired by the Library in the current financial year.

\section{Circulation}

5.I Circulation of documents per annum is the count of all borrowing transactions or loans of library materials, including renewals. It is often regarded as a measure of the use made of library materials. Give total circulation figures where breakdowns into languages are not available.

5.2 Give circulation figures of other materials that are available in the Library.

5.3 OPTIONAL. In-house use. Especially in public libraries, circulation is often not a true reflection of the total use of a library's materials. It is therefore suggested that some Libraries might wish to measure their inhouse use, in which case it should be done as follows:

A period has to be fixed for sampling. (Choose either one month or four separate weeks during the year.) During this period ask the users not to reshelve documents used in the library. Count every document before reshelving. An effort should be made to reshelve used documents as quickly as possible. Also calculate the number of days in the year that the Library was open. The formula for calculating annual in-house use will therefore be:

number of documents counted in sampling period $x$ total number open days per year

number of open days in sampling period

6 Our official definition of interlibrary loan is "a transaction in which library material, or a copy of the material (including materials sent by telefacsimile or other forms of electronic transmission) is made available by one library to another upon request. It includes both lending and borrowing. The libraries involved in interlibrary loan are not under the same administration or on the same campus (ANSI/NISO Z39.7-1995)."

For the purposes of this survey we wish to distinguish between documents requested by other libraries (lending) and documents received from other libraries (borrowing); and also documents borrowed to and lent from other libraries within a particular system (sometimes known as 'interbranch loans'). These two sets of numbers should be recorded separately.

7 Operating Cost explores the sources of funds expended during the previous completed financial year. Please distinguish if possible between funds from provincial and municipal governments. All other sources of funds (e.g. cost recovery schemes, funds collected by Friends or other organizations, rent paid for use of facilities, etc.) should be added together and reflected in the "Other" column. If detailed breakdowns are not available, please supply the total amount for the LIBRARY only in the final TOTAL column.

SA Jnl Libs \& Info Sci 2005, 7I (I) 
8 Expenditure. This section is to be completed by Provincial Library Authorities and Metro Libraries only. Give the total expenditures where breakdowns into languages are not available. Only the total expenditure on all kinds of other library materials, is required.

9 Facilities available include equipment, study places and other library amenities provided for library users. Examples of facilities are photocopiers, on-line terminals, CD-ROM, workstations, seats for reading and study carrels.

Give the total number of photocopier machines available in the Library.

Seats include all publicly available seats in seminar rooms or group study rooms, informal seats with no table or workspace, and seats at tables, but without equipment.

10 Use of facilities: number of users per annum. Note that the number of users should be counted manually, using registration logs. Count each user that uses electronic resources, regardless of the time spent on the computer. A user who uses the library's electronic resources three times a week would count as three customers (from NCES).

II Staff. Count staff in the highest column applicable, e.g. count a staff member with both a degree and a diploma in the column "Qualified with degree'.

Count all university degrees and equivalents (e.g. B.Tech.) as degrees. Count all university, technikon, technical college and post-matric diplomas from other educational institutions as diplomas.

12 User Assistance: A reference query is defined as "an information contact that involves the knowledge, use, recommendations, interpretation or instruction in the use of one or more information sources by a member of the library staff" (from the PROLIB study citing a definition by the Integrated Postsecondary Education Data System in the USA).

Count all the Reference and information queries answered by members of the library staff per annum.

13 Formal library orientation in groups refers to group sessions held in the Library to instruct users (adults or children) in the use of the Library, its materials or its facilities. Count both the number of the groups and the number of individuals in the groups.

I4 Library floor area in square metres. Count the entire area enclosed by the outside walls of the Library. Include space that is rented for the use of Library purposes.

15 Hours of opening. Give the total number of hours a library is open to the public from Monday to Sunday on an average week.

16 Extension services per annum. Only record extension activities that actually take place in the Library. Give any other activities not individually specified under 16.6 "Other activities".

17 Community involvement. Please specify any other community organizations or structures that are specifically concerned with library matters. 